\title{
Rickettsia felis (Rickettsiales: Rickettsiaceae) in Ctenocephalides felis felis (Siphonaptera: Pulicidae) in the State of São Paulo, Brazil
}

[Rickettsia felis (Rickettsiales: Rickettsiaceae) em Ctenocephalides felis felis (Siphonaptera: Pulicidae) no estado de São Paulo]

\author{
M.C. Horta ${ }^{1}$, A. Pinter $^{1}$, A. Cortez ${ }^{1}$, R.M. Soares ${ }^{1}$, S.M. Gennari ${ }^{1}$, T.T.S. Schumaker ${ }^{2}$, M.B. Labruna ${ }^{1}$ \\ ${ }^{1}$ Faculdade de Medicina Veterinária e Zootecnia - Universidade de São Paulo \\ Av. Prof. Orlando Marques de Paiva 87 \\ 05508-000 - São Paulo, SP \\ ${ }^{2}$ Instituto de Ciências Biomédicas - Universidade de São Paulo
}

\begin{abstract}
Samples of 10 and 14 Ctenocephalides felis felis fleas were collected on dogs from Pedreira and Mogi das Cruzes municipalities, respectively, in the State of São Paulo, Brazil, for detection of Rickettsia spp. Individual fleas were submitted to Polymerase Chain Reaction targeting the $17-\mathrm{kDa}$ and the $190-\mathrm{kDa}$ $(O m p A)$ genes of Rickettsiae. This later gene is specific for spotted fever group. Nine fleas from Pedreira $(90 \%)$ and four fleas from Mogi das Cruzes $(28 \%)$ were positive for the $17-\mathrm{kDa}$ gene, and eight fleas from Pedreira (80\%) and four from Mogi das Cruzes (28\%) were positive for $190-\mathrm{kDa}$ gene. The nucleotide sequence of the $190-\mathrm{kDa}$ products of one flea from Pedreira and one flea from Mogi das Cruzes were $100 \%$ identical to each other, and when compared to the GenBank Data, they were $100 \%$ identical to the 190-kDa sequence of R. felis. This was the first report of its occurrence in the State of São Paulo.
\end{abstract}

Keywords: Rickettsia felis, Ctenocephalides felis felis, dog, 190-kDa gene, Brazil

\section{RESUMO}

Amostras de 10 e 14 pulgas Ctenocephalides felis felis foram coletadas de cães nos municipios de Pedreira e Mogi das Cruzes, respectivamente, no estado de São Paulo, para pesquisa de Rickettsia spp. As pulgas foram individualmente submetidas à reação em cadeia pela polimerase, tendo como alvo os genes 17-kDa e 190-kDa (OmpA) de Rickettsia, sendo esse último especifico para o GFM. Nove pulgas de Pedreira (90\%) e quatro pulgas de Mogi das Cruzes (28\%) foram positivas para o gene 17-kDa, e oito pulgas de Pedreira (80\%) e quatro de Mogi das Cruzes (28\%) foram positivas para o gene 190-kDa. As seqüencias de nucleotídeos do gene 190-kDa de uma pulga de Pedreira e de uma pulga de Mogi das Cruzes foram 100\% idênticas; quando comparadas com dados existentes no GenBank, foram 100\% idênticas com a seqüencia parcial do gene 190-kDa de Rickettsia felis. Esse foi o primeiro relato de sua ocorrência no estado de São Paulo.

Palavras-chave: cão, Rickettsia felis, Ctenocephalides felis felis, gene 190-kDa

Suporte financeiro: FAPESP

Recebido para publicação em 6 de novembro de 2003

Recebido para publicação, após modificações, em 30 de junho de 2004

E-mail: maurivet@yahoo.com 


\section{INTRODUCTION}

The genus Rickettsia is currently composed by few more than 20 recognized species, which have mostly been associated with hematophagous arthropods, such as ticks, mites, lice and fleas (Stenos and Walker, 2000). Some of these species cause disease in humans and/or animals, to which they are transmitted via the arthropod vectors. In humans, rickettsiosis are generally acute diseases characterized classically by fever, headache, and in some cases, rash. Many other Rickettsia species are considered non-pathogenic or of unknown pathogenicity to humans.

Currently, genotypic identification by molecular techniques is much more used and has also allowed the characterization of previously uncultured species, such as Rickettsia felis (Bouyer et al., 2001). R. felis was first observed by Adams et al. (1990) in the midgut of cat fleas Ctenocephalides felis felis, and confirmed later as a new species by the use of genotypic characterization (Bouyer et al., 2001). Only recently, this species could be first cultured in laboratory (Raoult et al., 2001). By today, $R$. felis-infected fleas have been reported in some localities in the United States (Boostrom et al., 2002), Spain (Márquez et al., 2002), France (Rolain et al., 2003), United Kingdon (Kenny et al., 2003), Ethiopia (Raoult et al., 2001), Thailand (Parola et al., 2003), New Zealand (Kelly et al., 2004), Mexico (Zavala-Velázquez et al., 2002), Peru (Pachas et al., 2001) and in the state of Minas Gerais, Brazil (Oliveira et al., 2002). Moreover, human cases of a rickettsioses caused by $R$. felis have been reported in United States, France, Brazil; Germany; Mexico and Thailand (Schriefer et al., 1994; Raoult et al., 2001; Richter et al., 2002; Parola et al., 2003).

This study aimed to determine the Rickettsia felis occurrence in fleas collected on dogs from two Brazilian Spotted Fever endemic municipalities in the State of São Paulo.

\section{MATERIAL AND METHODS}

A sample of 10 adult fleas were collected on a resident dog from a farm near the Jaguari River, in Pedreira municipality $\left(22^{\circ} 47^{\prime} \mathrm{S}, 46^{\circ} 54^{\prime} \mathrm{W}\right)$, and another sample of 14 adult fleas was collected on a dog from a farm in the district of Taiaçupeba, Mogi das Cruzes municipality $\left(23^{\circ} 38^{\prime} \mathrm{S}, 46^{\circ} 11^{\prime} \mathrm{W}\right)$, both in the State of São Paulo. These two farms are located within the known endemic areas for human Brazilian spotted fever in the State of São Paulo (Melles et al., 1999; Lemos et al., 2001).

Fleas were collected alive and placed in dry plastic vials covered by a cork, containing few minute holes. Fleas from each locality were put together in a single vial. The vials were held under conditions of high humidity $(>80 \%)$ and temperature around $24^{\circ} \mathrm{C}$ during transportation to the laboratory, where fleas were taxonomically identified (Linardi and Guimarães, 2000) and placed in a freezer at $-80^{\circ} \mathrm{C}$ until molecular analysis.

Individual fleas were immersed in iodine alcohol for $10 \mathrm{~min}$ followed by two washes in distilled water. Each flea was triturated in $40 \mu$ l of TE buffer $\quad(10 \mathrm{mM} \quad$ Tris $\mathrm{HCl}$; $1 \mathrm{mM}$ ethylenediaminetetracetic acid (EDTA) $\mathrm{pH}$ 8.0) in a sterile mortar with the aid of a sterile alundum, which were previously washed in cloridric acid $(\mathrm{HCl} 0.1 \mathrm{~N})$ followed by heating at $250^{\circ} \mathrm{C}$ for 120 minutes to prevent any cross contamination. The resultant flea suspension was boiled at $100^{\circ} \mathrm{C}$ for 20 minutes and held at $-20^{\circ} \mathrm{C}$ until testing by polymerase chain reaction (PCR).

Extraction of flea DNA, PCR reaction set up and gel analysis of PCR products occurred in physically separated areas using different sets of pipetting devices and cotton-plugged pipette tips. For PCR, the boiled suspension from each triturated flea was used as DNA template to attempt the amplification of the rickettsial gene of the $17-\mathrm{kDa}$ and $190-\mathrm{kDa}$ proteins. For the 17$\mathrm{kDa}$ gene, it was used the primers ${ }^{1}$ PK-1 GCTCTTGCAACTTCTATGTT and PK-2 CATTGTTCGTCAGGTTGGCG, which amplify a 434-bp fragment of most of the Rickettsia species (Webb et al., 1990). For the 190-kDa $(O m p A)$ gene, it was used the primers $\mathrm{Rr}$ $190.70 \mathrm{P}$ - ATGGCGAATATTTCTCCAAAA and $\mathrm{Rr}-190.602 \mathrm{n}$

AGTGCAGCATTCGCTCCCCCT, which amplifies a 532-bp fragment of the $190-\mathrm{kDa}$

\footnotetext{
${ }^{1}$ Invitrogen-California, USA
} 
protein gene $(O m p A)$ of all Rickettsia species of the spotted fever group (SFG) (Regnery et al., 1991). For each reaction, $5 \mu 1$ of an individual flea DNA template were added to the follow PCR reagents ${ }^{1}: 5 \mu 1$ of PCR buffer (10X), $8 \mu$ of deoxynucleotide triphosphates mixture (1.25mM), $1.5 \mu \mathrm{l} \mathrm{MgCl}_{2}(50 \mathrm{mM}), 25 \mathrm{pmol}$ of each primer, $(0.25 \mu \mathrm{l}$ of $\mathrm{Taq}$ polymerase $(5000$ $\mathrm{U} / \mathrm{ml}$ ), and bi-distilled water to a final volume of $50 \mu 1$. Aliquots of this same water were used as template for the PCR negative controls. Reactions were performed in an automated DNA thermocycler ${ }^{2}$. For the $17-\mathrm{kDa}$ PCR, the following thermal conditions were employed: an initial denaturation at $94^{\circ} \mathrm{C}$ for $5 \mathrm{~min}$, followed by 35 cycles of $94^{\circ} \mathrm{C}$ for $45 \mathrm{sec}, 56^{\circ} \mathrm{C}$ for $30 \mathrm{sec}$ and $72^{\circ} \mathrm{C}$ for $2 \mathrm{~min}$, and finally $72^{\circ} \mathrm{C}$ for $10 \mathrm{~min}$. For the $190-\mathrm{kDa}$ PCR, the following thermal conditions were employed: $94^{\circ} \mathrm{C}$ for $5 \mathrm{~min}$, followed by 35 cycles of $95^{\circ} \mathrm{C}$ for $40 \mathrm{sec}, 58^{\circ} \mathrm{C}$ for $30 \mathrm{sec}$ and $65^{\circ} \mathrm{C}$ for $45 \mathrm{sec}$, and finally $72^{\circ} \mathrm{C}$ for $10 \mathrm{~min}$. PCR products were visualized by electrophoresis in $1.5 \%$ agarose gels ${ }^{1}$ with a 100 bp molecular weight ladder ${ }^{1}$ stained by ethidium bromide $\left(0.5 \mu \mathrm{g} / \mathrm{ml}^{10}\right)$.

PCR products showing a band of the expected size for the 190-kDa PCR, obtained from an individual flea from Pedreira and another flea from Mogi das Cruzes were purified and their forward and reverse nucleotide sequences were determined in a DNA sequencer analyzer ${ }^{3}$ using the same PCR conditions described above. The resultant sequences were compared to other rickettsial sequences available in the GenBank/EMBL Databases.

\section{RESULTS}

All 24 fleas collected in this study were identified as Ctenocephalides felis felis. Nine of the 10 fleas from Pedreira (90\%) and four of the 14 fleas from Mogi das Cruzes (28\%) were positive for the $17-\mathrm{kDa}$ gene, showing expected bands compatible with the 434-bp size (Fig. 1). When these same fleas were tested for the 190$\mathrm{kDa}$ gene, eight fleas from Pedreira $(80 \%)$ and four from Mogi das Cruzes (28\%) were positive, showing expected bands compatible with the

\footnotetext{
2 PTC-200 - MJ Research - Massachusetts, USA

3 ABI Prism 310 Genetic - Applied Biosystens/Perkin Elmer, California, USA
}

532-bp size. All fleas positive for the 190-kDa gene were also positive for the $17-\mathrm{kDa}$ (i.e. only one flea from Pedreira was positive for the 17$\mathrm{kDa}$ gene and negative for the 190-kDa gene). Amplification was unsuccessfully in all negative controls.

The nucleotide sequence of the $190-\mathrm{kDa}$ products of one flea from Pedreira and one flea from Mogi das Cruzes were 100\% identical to each other, and when compared to the GenBank Data, they were $100 \%$ identical to the $190-\mathrm{kDa}$ available sequence of $R$. felis [AF191026].

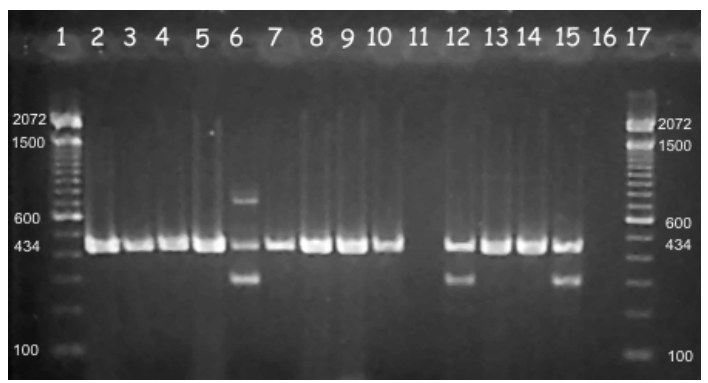

Figure 1. PCR products derived from the $17 \mathrm{kDa}$ gene. Line 1: genetic marker; lines 2-10: individual fleas from Pedreira; line 11: negative control (water); lines 12-15: individual fleas from Mogi das Cruzes; line 16: negative control (water); line 17: genetic marker.

\section{DISCUSSION}

Due to the several reports of $R$. felis among different countries, it was suggested that it might have a worldwide distribution (Zavala-Velázquez et al., 2002). As a contribution for the life history of this new Rickettsia species, this study comprises the second report of $R$. felis from fleas in Brazil, and the first from the State of São Paulo. A previous study reported the presence of $R$. felis in Ctenocephalides sp fleas from Coronel Fabriciano Municipality, State of Minas Gerais (Oliveira et al., 2002). The presence of R. felis was confirmed in two $C$. felis felis fleas, from two different areas, by sequencing the PCR product corresponding to the $190-\mathrm{kDa}$ gene. The two fleas were also positive for the 17-kDa gene, PCR. This latter gene has been found in different Rickettsia species from both typhus group (TG) and spotted fever group (SFG), but the 190-kDa gene is restricted to SFG species, which includes $R$. felis (Bouyer et al., 2001). It is noteworthy that no previous work with fleas or $R$. felis had 
been conducted in the laboratory. This minimizes any possibility of external contamination of these samples.

Currently, the only Rickettsia species reported in Ctenocephalides fleas are R. felis and Rickettsia typhi (Azad et al., 1997; Bouyer et al., 2001). R. typhi is the etiologic agent of murine typhus and has also been reported in Brazil (Linardi and Guimarães, 2000). Although only two PCR products out of 12 positive fleas for the $190-\mathrm{kDa}$ gene were sequenced in the present study, the remaining 10 fleas were probably also infected by $R$. felis, as $R$. typhi can not be detected by the $190-\mathrm{kDa}$ gene primers used in the present study (Regnery et al., 1991). At least one flea from Pedreira was positive for the $17-\mathrm{kDa}$ gene but negative for the $190-\mathrm{kDa}$ gene, suggesting a TG Rickettsiae. Unfortunately, no extra DNA of this particular flea was available, and then the sequence of its PCR product could not be determined. DNA of $R$. felis and $R$. typhi have been detected in $C$. felis felis from common areas of the United States. Generally, infection rates for $R$. felis are higher than those for $R$. typhi (Azad et al., 1997; Boostrom et al., 2002).

Although small flea samples (10 fleas from Pedreira and 14 fleas from Mogi das Cruzes) were tested, the proportions of positive fleas for the $190-\mathrm{kDa}$ gene (presumably $R$. felis) were high, especially in the Pedreira sample, where $80 \%$ were positive. In another study with $C$. felis felis collected on dogs and cats from Spain, seven out of 14 pools of fleas were positive for R. felis (Márquez et al., 2002). Although the proportion of infection by $R$. felis among C. felis felis from United States has been reported to be higher than $80 \%$ among commercial and laboratory flea colonies, the proportions among wild-caught fleas have been less than 5\% (Boostrom et al., 2002; Wedincamp and Foil 2002). Thus, the present study reports the highest proportion of $R$. felis-positive fleas among wildcaught fleas. Although transovarial transmission and transstadial survival of $R$. felis in $C$. felis felis has been well documented, either the mechanism by which naïve fleas acquire new infections and the mechanism of transmission of the pathogen by an infected flea are not clarified (Wedincamp and Foil, 2002). Even though these results could be affected by a potential transient rickettsemia in the dogs when the fleas where collected, it is also unknown if dogs can be infected by $R$. felis. Even if they were, an efficient reservoir must develop a rickettsemia above the threshold sufficient to infect fleas feeding on them. In regard to $R$. rickettsii, Norment and Burgdorfer (1984) proved that dogs experimentally inoculated with $R$. rickettsii became infected and ill but were not an efficient source of infection for feeding ticks. Another possible way that could have potentially contributed to our high proportion of positive fleas was the fact that fleas collected on each dog were held and transported to laboratory, together in a single vial. However, horizontal transmission of $R$. felis between fleas has never been proved, even when infected fleas were held in direct contact with uninfected fleas (Wedincamp and Foil, 2002). In addition, our fleas were individually surface-sterilized and washed twice in distilled water prior to analysis.

The high proportion of $R$. felis-infected C. felis felis reported in this study appoint for the circulating of the agent in both areas (Pedreira and Mogi das Cruzes). In the two areas, the dogs were reared unrestrained, with free access to forests and bushes, sharing the same habitats with domestic and wild animals. The role of dogs in the life history of $R$. felis (other than being a primary host for $C$. felis felis) is unknown. Opossums (Didelphis virginiana) have been reported as competent reservoirs of both $R$. felis and $R$. typhi in the United States (Azad at al., 1997; Boostrom et al., 2002). South American opossums (Didelphis albiventris and Didelphis aurita) were abundant in both areas of the present study (data not shown).

Both findings of $R$. felis in Brazil (Oliveira et al., 2002 and the present study) were conducted in areas where recent human cases of Brazilian spotted fever (BSF) have been reported. These BSF cases were clinically (high case fatality rates) and epidemiologically (recent historic of tick bite) compatible with infection due to $R$. rickettsii, and were diagnosed by serologic-based techniques, such as immunofluorescence assay (IFA) and immunohistochemical of tissue samples, or by isolation of the agent in cell culture (Melles et al., 1999; Lemos et al., 2001; Oliveira et al., 2002). Although the disease caused by $R$. felis in humans seems to be less severe than the disease caused by $R$. rickettsii (i.e. no lethal cases due to $R$. felis has been reported), a differential diagnosis of both agents 
should be provided in these areas where both agents seem to coexist. Moreover, $R$. felis is a novel agent and many clinical and ecological features of its life history are yet to be explored.

\section{ACKNOWLEDMENTS}

To the Health Municipal Office of Mogi das Cruzes and Pedreira, and to the farm residents in both localities of the present study for their valuable support during the present study. This work was supported by FAPESP (processes No. 00/02711-1, No. 00/02710-5 and 01/01218-2).

\section{REFERENCES}

ADAMS，J.R.; SCHMIDTMAN， E.T.; AZAD， A.F. Infection of colonized cat fleas Ctenocephalides felis (Bouché) with a Rickettsia-like microorganism. Am. J. Trop. Med. Hyg., v.43, p.400-409, 1990.

AZAD, A.F.; RADULOVIC, S.; HIGGINS, J.A. et al. Flea-borne Rickettsioses: ecologic considerations. Emerg. Infect. Dis., v. 3, p.319-327, 1997.

BOOSTROM, A.; BEIER, M.S.; MACALUSO, J.A. et al. Geographic association of Rickettsia felis-infected opossums with human murine typhus, Texas. Emerg. Infect. Dis., v.8, p.549-554, 2002.

BOUYER, D.H.; STENOS, J.; VALDES, P.C. et al. Rickettsia felis: Molecular characterization of a new member of the spotted fever group. Int. J. Syst. Evolut. Microbiol., v.51, p.339-347, 2001.

KELLY, P.J.; MEADS, N.; THEOBALD, A. et al. Rickettsia felis, Bartonella henselae, and B. clarridgeiae, New Zealand. Emerg. Infect. Dis., v.10, p.967-968, 2004.

KENNY, M.J.; BIRTLES, R.J.; DAY, M.J. et al. Rickettsia felis in the United Kingdom. Emerg. Infect. Dis., v.8, p.1023-1024, 2003.

LEMOS, E.R.; ALVARENGA, F.B.; CINTRA, M.L. et al. Spotted fever in Brazil: a seroepidemiological study and description of clinical cases in an endemic area in the state of São Paulo. Am. J. Trop. Med. Hyg., v.65, p.329334, 2001.

LINARDI, P.M.; GUIMARÃES, L.R. (Ed.). Sifonápteros do Brasil. São Paulo, 2000. 291p.

MÁRQUEZ, F.J.; MUNIAN, M.A.; PÉREZ, J.M. et al. Presence of Rickettsia felis in the cat flea from southweastern Europe. Emerg. Infect. Dis., v.8, p.89-91, 2002.

MELLES, H.H.B.; COLOMBO, S.; LEMOS, E.R.S. Isolamento de Rickettsia em cultura de células vero. Rev. Soc. Bras. Med. Trop., v.32, p.469-473, 1999.

NORMENT, B.R.; BURGDORFER, W. Susceptibility and reservoir potential of the dog to spotted fever-group Rickettsiae. Am. J. Vet. Res., v.45, p.1706-1710, 1984.
OLIVEIRA, R.P.; GALVÃO, M.A.M.; MAFRA, C.L. et al. Rickettsia felis in Ctenocephalides spp. fleas, Brazil. Emerg. Infect. Dis., v.8, p.317-319, 2002.

PACHAS, P.; MORON, C.; HOYOS, A. et al. Rickettsia felis indentified in Ctenocephalides canis fleas from the Peruvian Andes [abstract 16]. In: American Society for Rickettsiology - Bartonella as an emerging pathogen group - 2001 Joint Conference, Big Sky, Montana, USA, 2001.

PAROLA, P.; SANOGO, O.Y.; LERDTHUSNEE, K. et al. Identification of Rickettsia spp. and Bartonella spp. in fleas from the Thai-Myanmar Border. Ann. N. Y. Acad. Sci., v.990, p.173-181, 2003.

PHILIP, R.N.; CASPER E.A.; BURGDORFER W. et al. Serologic typing of Rickettsiae of the Spotted Fever Group by microimmunofluorescence. J. Immunol., v.121, p.1961-1968, 1978.

RAOULT, D.; LA SCOLA, B.; ENEA, M. et al. A fleaassociated Rickettsia pathogenic for humans. Emerg. Infect. Dis., v.7, p.73-81, 2001.

REGNERY, R.L.; SPRUILL, C.L.; PLIKAYTIS B.D. et al. Genotypic identification of Rickettsiae and estimation of intraspecies sequence divergence for portions of two rickettsial genes. J. Bacteriol., v.173, p.1576-1589, 1991.

RICHTER, J.; FOURNIER, P.E.; PETRIDOU, J. et al. Rickettsia felis infection acquired in Europe and documented by polymerase chain reaction. Emerg. Infect. Dis., v.8, p.207-208, 2002.

ROLAIN, J.M.; FRANC, M.; DAVOUST, B. et al. Molecular detection of Bartonella quintana, B. koehlerae, $B$. henselae, B. clarridgeiae, Rickettsia felis, and Wolbachia pipientis in cat fleas, France. Emerg. Infect. Dis., v.9, p.338-342, 2003.

SCHRIEFER, M.E.; SACCI, J.B.; DUMLER, J.S. et al. Identification of a novel rickettsial infection in a patient diagnosed with murine typhus. J. Clin. Microbiol., v.32, p.949-954, 1994.

STENOS, J.; WALKER, D.H. The rickettsial outermembrane protein A and B genes of the Rickettsia australis, the most divergent rickettsia of the spotted fever group. Int. J. Syst. Evolut. Microbiol., v.50, p.17751779, 2000.

WEBB, L.; CARL, M.; MALLOY, D.C. et al. Detection of murine typhus infection in fleas by using the polymerase chain reaction. J. Clin. Microbiol., v.28, p.530-534, 1990

WEDINCAMP, J.; FOIL, L.D. Vertical transmission of Rickettsia felis in the cat flea (Ctenocephalides felis Bouché). J. Vec. Ecol., v.27, p.96-101, 2002.

ZAVALA-VELÁZQUEZ, J.E.; ZAVALA-CASTRO, J.E.; VADO-SOLÍS, I. et al. Identification of Ctenocephalides felis fleas as a host of Rickettsia felis, the agent of spotted fever rickettsioses in Yucatán, Mexico. Vec. Borne. Zoon. Dis., v.2, p.69-75, 2002. 